\title{
IMPACT OF METEOROLOGICAL STORMS ON THE E-REGION OF THE IONOSPHERE IN 2017-2018
}

\author{
O.P. Borchevkina \\ West Department of Pushkov Institute of Terrestrial Mag- \\ netism, Ionosphere and Radio Wave Propagation RAS, \\ Kaliningrad, Russia, olgaborchevkina@gmail.com \\ Immanuel Kant Baltic Federal University, \\ Kaliningrad, Russia, olgaborchevkina@gmail.com

\section{I.V. Karpov} \\ West Department of Pushkov Institute of Terrestrial Mag- \\ netism, Ionosphere and Radio Wave Propagation RAS, \\ Kaliningrad, Russia, ivkarpov@inbox.ru \\ Immanuel Kant Baltic Federal University, \\ Kaliningrad,Russia, ivkarpov@inbox.ru

\section{M.I. Karpov} \\ West Department of Pushkov Institute of Terrestrial Mag- \\ netism, Ionosphere and Radio Wave Propagation RAS, \\ Kaliningrad, Russia, mikhailkarpov@hotmail.com
}

Immanuel Kant Baltic Federal University, Kaliningrad,Russia, mikhailkarpov@hotmail.com

\author{
N.A. Korenkova \\ West Department of Pushkov Institute of Terrestrial Mag- \\ netism, Ionosphere and Radio Wave Propagation RAS, \\ Kaliningrad,Russia,wdizmiran@gmail.com \\ V.I. Vlasov \\ West Department of Pushkov Institute of Terrestrial Mag- \\ netism, Ionosphere and Radio Wave Propagation RAS, \\ Kaliningrad,Russia,wdizmiran@gmail.com \\ V.S. Leshchenko \\ West Department of Pushkov Institute of Terrestrial Mag- \\ netism, Ionosphere and Radio Wave Propagation RAS, \\ Kaliningrad,Russia,wdizmiran@gmail.com
}

\begin{abstract}
The paper presents the results of observations of the sporadic $\mathrm{E}_{\mathrm{s}}$ layer during the period of meteorological disturbances in Kaliningrad in October 2017 and 2018 under quiet geomagnetic conditions. During the meteorological storms (October 29-30, 2017 and October 23-24, 2018), significant changes occurred in the dynamics of the $\mathrm{E}_{\mathrm{s}}$-layer critical frequency. Observations of atmospheric and ionospheric disturbances in the Kaliningrad region show that the delay between the ionospheric response and the moment of maximum disturbances in atmospheric parameters is about 3 hours. These phenomena at the heights of the E-region might have been caused by propagation of acoustic-gravity waves generated by convective
\end{abstract}

processes in the lower atmosphere during periods of a meteorological storm. Intensification of turbulent processes in the lower thermosphere leads to an increase in the atmospheric density and, accordingly, to higher recombination rates. This leads to a rapid decrease in the concentration of ions and, consequently, to a decrease in the critical frequency of the sporadic layer below the sensitivity threshold of ionosondes.

Keywords: sporadic E layer, acoustic-gravity waves, atmosphere-ionosphere coupling, meteorological disturbances.

\section{INTRODUCTION}

Great emphasis is now placed on the study of ionospheric disturbances driven by powerful dynamic processes in the lower atmosphere and on Earth's surface. Experimental studies show that the development of these processes leads to ionospheric disturbances. For example, storms and hurricanes are accompanied by strong disturbances of ionospheric F2-layer parameters and total electron content (TEC) [Martinis, Manzano, 1999; Zakharov, Kunitsyn, 2012; Polyakova, Perevalova, 2013; Chernigovskaya et al., 2014, 2015; Koucká Knížová et al., 2015; Bogdanov et al., 2016; Karpov et al., 2016, 2019; Borchevkina, Karpov, 2017].

Hypotheses about the mutual influence of processes in different atmospheric layers are based on ideas about generation of atmospheric waves, in particular acoustic gravity waves (AGWs), and their propagation under certain conditions from below into the upper atmosphere [Kazimirovsky et al., 2003; Lastovicka, 2006, Mathews, 1998]. Powerful meteorological processes (storms, hurricanes, and typhoons) are a source of AGW generation in the atmosphere. Theoretical studies indi- cate that meteorological sources excite relatively shortperiod AGWs [Snively, Pasko, 2003; Kunitsyn et al., 2007]. AGWs with periods close to the Brunt-Väisälä period and infrasonic waves propagating from an excitation region can reach thermospheric and ionospheric heights [Schubert et al., 2005]. Dissipation of these waves leads to the formation of local heating regions in the thermosphere that affects the dynamics and ionization-recombination processes in the ionosphere [Karpov, Kshevetskii, 2014; Karpov, Kshevetskii, 2017]. The processes that are caused by dissipation of AGWs, excited during meteorological disturbances, and influence ionospheric effects in the F-region may be ineffective at E-region heights. Theoretical studies [Karpov, Kshevetskii, 2014; Karpov, Kshevetskii, 2017] indicate that the region of dissipation of such waves is usually located at heights $250-300 \mathrm{~km}$, i.e. well above the E layer.

It has been established that in the lower ionosphere at E-layer heights there is a link between the AGW activity manifestation and disturbances of characteristics of sporadic E layers ( $\mathrm{E}_{\mathrm{s}}$ layers). Specifically, cases have been found in which an $\mathrm{E}_{\mathrm{s}}$ layer and a disturbance in the F-region exhibited the same periodicity [van Eyken et al., 1982, 
Mathews, 1998; Parkinson, Dyson, 1998]. Various aspects of the AGW impact on $E_{s}$ layers such as the impact of waves on the inhomogeneity of horizontal winds at ionospheric E-layer heights, disturbances of the layer critical frequency, and recombination processes in the upper mesosphere - lower thermosphere are discussed in [Pilipenko, Kozak, 2012; Barta et al., 2017; Haldoupis, 2012; Šauli, Bourdillon, 2008; Didebulidze et al., 2015].

Thus, further development of ideas about dynamics of the lower ionosphere under conditions of meteorological disturbances involves collecting observational data and improving the physical interpretation of the phenomena observed.

The purpose of this study is to analyze variations in parameters of the lower atmosphere and $\mathrm{E}_{\mathrm{s}}$ layer during meteorological storms in Kaliningrad in October 2017 and 2018.

\section{OBSERVATIONAL DATA}

The peculiarity of the geographical location of the south-east Baltic, where Kaliningrad is located, is that it is open to penetration of westerly transitional air masses. According to long-term meteorological observations, the number of days with strong winds $(>15 \mathrm{~m} / \mathrm{s})$ in the Kaliningrad region is $28-38$ per year; in some years, up to 60 days; in the fall-winter season (November-January), about half of all stormy days. The force of the storms observed is typically 7-8 $(12-18 \mathrm{~m} / \mathrm{s})$, rarely $9-10(18-25 \mathrm{~m} / \mathrm{s})$; in exceptional cases, 11-12 (>25 m/s). Transit of Atlantic cyclones occurs in the absence of orographic obstacles, which determines the local wind regime [Tupikin, 2003].

The meteorological extreme phenomena emerging under such conditions may affect the stability of operation of various communication and navigation systems, among them the satellite systems GLONASS and GPS [Karpov et al., 2019].

In this paper, we analyze disturbances of the lower ionosphere, using observations made at the station Kaliningrad $\left(54^{\circ} \mathrm{N}, 20^{\circ} \mathrm{E}\right)$ during meteorological storms in October 2017 and 2018. To describe the meteorological conditions, we use three-hour measurements of a maximum wind speed as well as of the atmospheric pressure reduced to the mean sea level, from [https://rp5.ru]. As an additional source of data, we have utilized 1-hour measurements from the meteorological station Olsztyn $\left(53^{\circ} \mathrm{N}, 20^{\circ} \mathrm{E}\right)$, Poland. $\mathrm{E}_{\mathrm{s}}$-layer variations were determined from $15 \mathrm{~min}$ measurements of the critical frequency $f_{\mathrm{o}} \mathrm{E}_{\mathrm{s}}(\mathrm{MHz})$ and the minimum operating height $h^{\prime} \mathrm{E}_{\mathrm{s}}(\mathrm{km})$ from the ionosonde Parus-A at the test site of the Kaliningrad Branch of IZMIRAN $\left(54.36^{\circ} \mathrm{N}, 20.12^{\circ} \mathrm{E}\right)$.

Meteorological storms are events accompanied by a very strong prolonged (more than $6 \mathrm{hrs}$ ) wind, usually when a cyclone causes heavy sea and more or less damage to onshore infrastructure. The wind with a speed $17-24 \mathrm{~m} / \mathrm{s}$ is classified as a storm and severe storm (8-9 on the Beaufort scale) [Khromov, Mamontova, 1974].

For the analysis, we have selected the meteorological storms (October 29-30, 2017 and October 23-24, 2018) such that the maximum wind speed in Kaliningrad was as high as $17 \mathrm{~m} / \mathrm{s}$ or higher, which corresponds to force 8 and above on the Beaufort scale. These events occurred under low geomagnetic and solar activity. A criterion for quiet conditions was the geomagnetic activity index $K_{\mathrm{p}} \leq 3$ during the event or the previous day; $-20 \leq D s t \leq 20 \mathrm{nT}$ that did not change by more than $20 \mathrm{nT}$ within 24 hours.

Figure 1 presents three-hour measurements of maximum wind gust speeds, atmospheric pressure, reduced to the mean sea level, from [https://rp5.ru], as well as variations in the geomagnetic indices during the October 2017 and 2018 storms.

The Figure indicates that the analyzed events happened under quiet geomagnetic conditions and disturbed (storm) conditions in the lower atmosphere.

Figures 2, 3 depict variations in the critical frequency $\left(f_{\mathrm{o}} \mathrm{E}_{\mathrm{s}}, \mathrm{MHz}\right)$ and a minimum virtual height of the $\mathrm{E}_{\mathrm{s}}$ layer $\left(\mathrm{h}^{\prime} E_{\mathrm{s}}, \mathrm{km}\right)$ during the October 2017, 2018 storms.

It is apparent that during the meteorological disturbances (October 29-30, 2017 and October 23, 2018), $\mathrm{E}_{\mathrm{s}}$ layer characteristics change which shows up as a decrease in $f_{\mathrm{o}} \mathrm{E}_{\mathrm{s}}$ below the ionosonde sensitivity threshold $(\sim 2 \mathrm{MHz})$ and as a non-monotonic change in the layer height.

In October 2017, the meteorological storm began at 06 UT on October 29 and continued until 23 UT on October 30 (Figure 1). A rapid decrease in $f_{\mathrm{o}} \mathrm{E}_{\mathrm{s}}$ was observed after $12 \mathrm{UT}$, and from 17:00 UT on October 29 to 6:00 on October 30 and from 14:00 on October 30 to 07:00 on October 31 there was no sporadic layer detected (Figure 2). In October 2018, a depression near the station Kaliningrad was recorded from 06 UT on October 23 to 18 UT on October 24 (Figure 1). For some periods of the storms there is no data on meteorological conditions, which is likely to be linked to faulty groundbased equipment. The sporadic layer during that period disappeared from 14:00 on October 23 to 7:00 on October 24 (Figure 3). After the meteorological storms, the $\mathrm{E}_{\mathrm{s}}$ parameters returned to pre-storm values.

A significant decrease in $f_{\mathrm{o}} \mathrm{E}_{\mathrm{s}}$ and accordingly in the $\mathrm{E}_{\mathrm{s}}$ electron density, which is observed during the storm and is not observed before and after the event, allow us to attribute these ionospheric disturbances to the passage of the storm.

\section{DISCUSSION}

An accepted theory is now the wind shear theory [Mathews, 1998; Haldoupis, 2012] that attributes the formation of the sporadic E layers in the ionosphere at midlatitudes to ion flows caused by the irregular vertical structure of horizontal winds. Occurrence of the irregular neutral wind may be associated with different dynamic processes in the lower thermosphere [Haldoupis et al., 2006; Pignalberi et al., 2014].

Despite the sporadic appearance of the $\mathrm{E}_{\mathrm{s}}$ layer, variations of its parameters exhibit features indicating their regularity [Bryunelli, Namgaladze, 1988]. Thus, the observations of the $\mathrm{E}_{\mathrm{s}}$-layer dynamics (Figures 2, 3) clearly show nightside layers formed by metal ions, a dawn increase in height and $f_{\mathrm{o}} \mathrm{E}_{\mathrm{s}}$ on the days preceding the passage of the meteorological disturbances.

During the storms (October 29-30, 2017 and October 23-24, 2018), there were significant changes in the dynamics of the $\mathrm{E}_{\mathrm{s}}$-layer parameters. The sporadic layer 

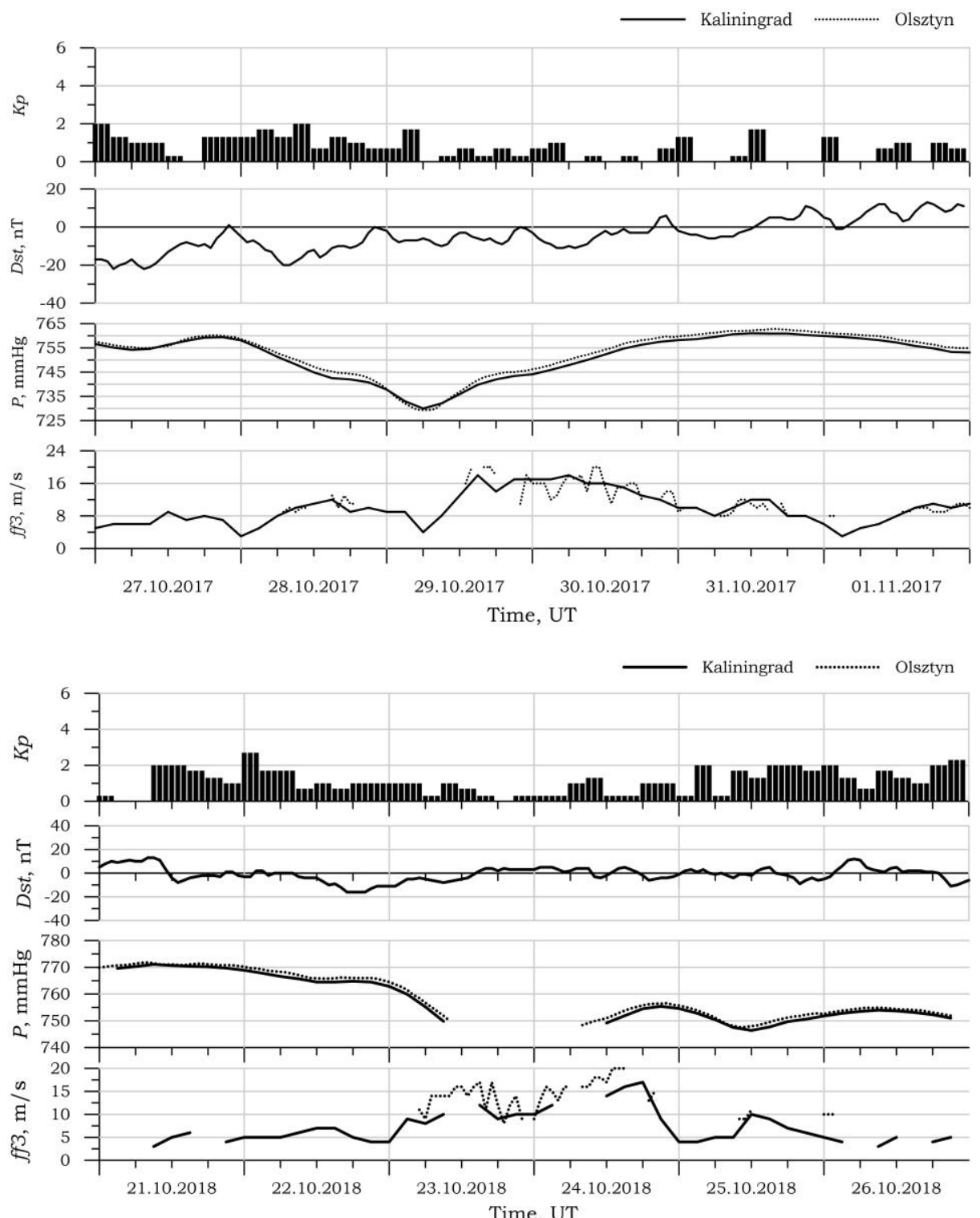

Figure 1. Variations in the atmospheric pressure $P$, maximum gust velocity ff3, geomagnetic activity indices $K_{\mathrm{p}}$ and $D s t$ in Kaliningrad and Olsztyn on October 27 - November 1, 2017 (a) and October 21-26, $2018(b)$

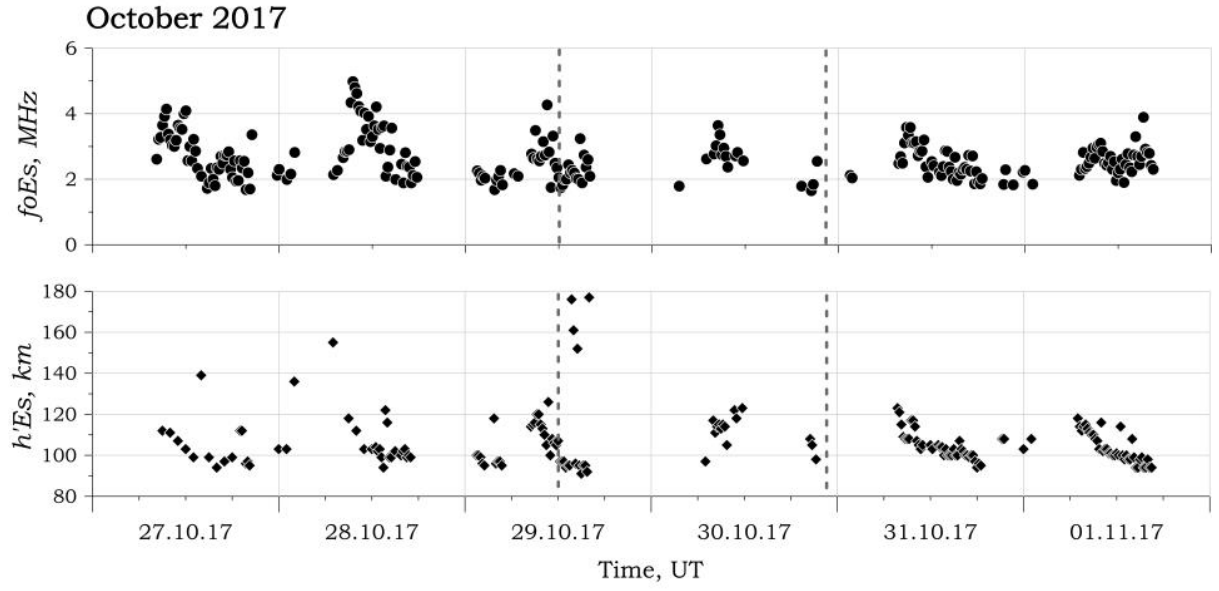

Figure 2. Time variations in the critical frequency $f_{\mathrm{o}} \mathrm{E}_{\mathrm{s}}$ and in the minimum height $h^{\prime} \mathrm{E}_{\mathrm{s}}$ of the sporadic $\mathrm{E}_{\mathrm{s}}$ layer on October 27 November 1, 2017, as derived from vertical sounding data obtained at the station Kaliningrad. Dashed lines indicate the time of the meteorological storm 


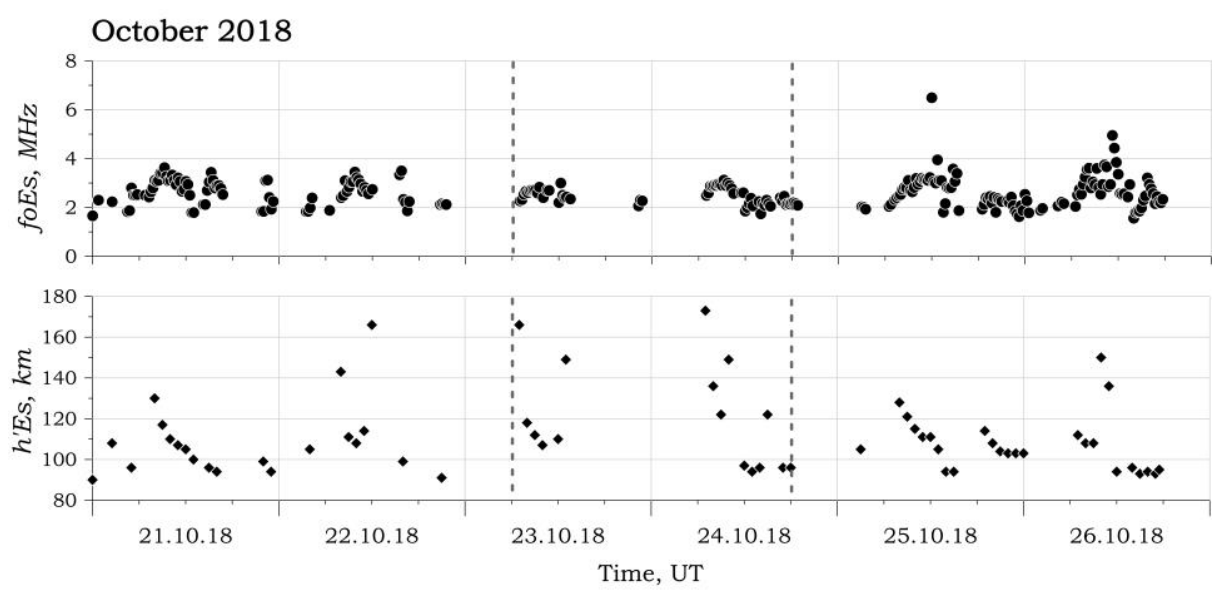

Figure 3. Time variations in the critical frequency $f_{\mathrm{o}} \mathrm{E}_{\mathrm{s}}$ and in the minimum height $h^{\prime} \mathrm{E}_{\mathrm{s}}$ of the sporadic $\mathrm{E}_{\mathrm{s}}$ layer on October 21-26, 2018, as derived from vertical sounding data obtained at the station Kaliningrad. Dashed lines show the time of the meteorological storm

in those periods was observed only in the daytime. After the end of the storms in the Kaliningrad region, the $\mathrm{E}_{\mathrm{s}}$-layer parameters return to the values detected on the days prior to the meteorological disturbances. Similar changes in the $\mathrm{E}_{\mathrm{s}}$-layer parameters occurred during the passage of summer thunderheads in Europe in 2013-2014 [Barta et al., 2017]. These studies have shown that 1-2 hrs after the thunderheads that passed through the survey coverage, $f_{\mathrm{o}} \mathrm{E}_{\mathrm{s}}$ decreased below the ionosonde sensitivity threshold $(\sim 2 \mathrm{MHz})$. Barta et al. [2017], by analyzing the observations, have concluded that the most likely cause of the $\mathrm{E}_{\mathrm{s}}$-layer disturbance is AGWs generated in the troposphere and mesosphere during the passage of thunderheads.

Observations of disturbances of atmospheric and ionospheric parameters in the Kaliningrad region (Figures 1-3) also suggest that the delay in the ionospheric response with respect to the time of maximum disturbances of atmospheric parameters is $\sim 3 \mathrm{hrs}$. These values are quite consistent with the concepts of ionospheric disturbances induced by AGWs of tropospheric origin. Note also that the results reported in this paper were obtained under conditions of storms occurring during the fall period without increasing lightning activity. Thus, AGWs were largely generated by convective processes in the troposphere.

The AGW impact on sporadic layers in the ionospheric E-region has been studied in numerous experimental and theoretical works [Mathews, 1998; Fukao et al., 1998; Parkinson, Dyson, 1998; Bourdillon et al., 1997; Scotto, 1995; Pilipenko, Kozak, 2012; Snively, Pasko, 2003; Liperovsky et al., 2000], which examined various aspects of the AGW impact, including the impact of waves on the irregularity of horizontal winds in the ionospheric E-region, the disturbance of the critical frequency in the layer, recombination processes in the upper mesosphere - lower thermosphere.

The short delays in the ionospheric response (2-3 hrs) to tropospheric disturbances enable us to limit the spectral range of AGWs excited in the atmosphere and penetrating to ionospheric heights. Snively, Pasko [2003] have shown that during meteorological disturbances short-period AGWs are excited which, propagating nearly vertically, can reach ionospheric heights within 2-3 hours. Similar conclusions can be drawn from [Karpov, Kshevetskii, 2014]. Dissipation effects of such AGWs due to their short periods are at heights $250-300 \mathrm{~km}$. In this case, we can assume that dissipation effects of such waves will not have a great impact on the $\mathrm{E}_{\mathrm{s}}$ dynamics.

On the other hand, vertical propagation of such waves and the amplitude increasing with height can lead to collapse of the waves at heights of the lower thermosphere, thus significantly affecting turbulent processes. Enhancement of the turbulent processes in the lower thermosphere causes the atmospheric density and the intensity of recombination processes to increase. As a result, the ionic concentration and, accordingly, $f_{\mathrm{o}} \mathrm{E}_{\mathrm{s}}$ decrease rapidly to frequencies below the ionosonde sensitivity threshold. We can assume that it is precisely these processes that lead to disturbances of the $\mathrm{E}_{\mathrm{s}}$-layer dynamics during meteorological disturbances.

\section{CONCLUSIONS}

We have reported observations of the atmospheric dynamics and the sporadic $\mathrm{E}_{\mathrm{s}}$ layer in the Kaliningrad region during two meteorological storms in October 2017 and 2018. The observations have shown that under quite strong meteorological disturbances, when a wind gust velocity reaches 8 and above on the Beaufort scale, there is a significant decrease in $f_{\mathrm{o}} \mathrm{E}_{\mathrm{s}}$. During such periods, the sporadic layer appears only in the daytime and disappears at night. The delay in the ionospheric response with respect to the time of occurrence of maximum disturbances of atmospheric parameters is $\sim 3 \mathrm{hrs}$. The response of the sporadic layer under meteorological disturbances closely resembles the ionospheric response observed during the passage of thunderheads.

The phenomena observed at E-region heights are likely caused by propagation of AGW generated by convective processes in the lower atmosphere during a meteorological storm. Taking into account the short delays (2-3 hrs) in the ionospheric response to disturb- 
ances in the lower atmosphere, we can assume that the AGW effect reveals itself in the intensification of turbulent processes in the lower thermosphere. This in turn leads to an increase in the density of the lower thermosphere and in the efficiency of recombination processes.

This work was supported by RFBR and Kaliningrad Government, grant No. 19-45-390005 (O.P. Borchevkina, M.I. Karpov) and RFBR grant No. 18-05-00184 (I.V. Karpov).

\section{REFERENCES}

Barta V., Haldoupis C., Sátori G., Buresova D., Chum J., Pozoga M., et al. Searching for effects caused by thunderstorms in midlatitude sporadic E layers. J. Atmos. Solar-Terr. Phys. 2017, vol. 161, pp. 150-159. DOI: 10.1016/j.jastp.2017.06.006.

Bogdanov V., Kaysin A., Romanov A. Impact of cyclones over Kamchatka on electron distribution in the ionosphere. E3S Web of Conferences. 2016, vol. 11, no. 00003. DOI: 10.1051/ e3sconf/20161100003.

Borchevkina O.P., Karpov I.V. Ionospheric irregularities in periods of meteorological disturbances. Geomagnetism and Aeronomy. 2017, vol. 57, no. 5, pp. 624-629. DOI: 10.1134/ S0016793217040041.

Bourdillon A., Lefur E., Haldoupis C., Le Roux Y., Menard J., Delloue J. Decameter mid-latitude sporadic-E irregularities in relation with gravity waves. Ann. Geophys. 1997, vol. 15, pp. 925-934. DOI: 10.1007/s00585-997-0925-1.

Bryunelli B.E., Namgaladze A.A. Fizika ionosfery [Physics of the Ionosphere]. Moscow, Nauka Publ., 1988, 528 p. (In Russian).

Chernigovskaya M.A., Kurkin V.I., Oinats A.V., Poddelsky I.N. Ionosphere effects of tropical cyclones over the Asian region of Russia according to oblique radio-sounding data. Proc. SPIE 9292 - The International Society for Optical Engineering. 2014, vol. 92925E. DOI: 10.1117/12.2073391.

Chernigovskaya M.A., Shpynev B.G., Ratovsky K.G. Meteorological effects of ionospheric disturbances from vertical radio sounding data. J. Atmos. Solar-Terr. Phys. 2015, vol. 136(B), pp. 235-243. DOI: 10.1016/j.jastp.2015.07.006.

Didebulidze G. G., Dalakishvili G., Lomidze L., Matiashvili G. Formation of sporadic-E $\left(\mathrm{E}_{\mathrm{s}}\right)$ layers under the influence of AGWs evolving in a horizontal shear flow. $J$. Atmos. Solar-Terr. Phys. 2015, vol. 136(B), pp. 163-173. DOI: 10.1016/ j.jastp.2015.09.012.

Fukao S., Yamamoto M., Tsunoda R. T., Hayakawa H., Mukai T. The SEEK (Sporadic-E Experiment over Kyushu) Campaign. Geophys. Res. Lett. 1998, vol. 25, no. 11, pp. 17611764. DOI: 10.1029/98GL00932.

Haldoupis C. Midlatitude sporadic E. A typical paradigm of atmosphere-ionosphere coupling. Space Sci. Rev. 2012, vol. 168, no. 1-4, pp. 441-461. DOI: 10.1007/s11214-011-9786-8.

Haldoupis C., Meek C., Christakis N., Pancheva D., Bourdillon A. Ionogram height-time-intensity observations of descending sporadic E layers. J. Atmos. Solar-Terr. Phys. 2006, vol. 68, iss. 3-5, pp. 539-557. DOI: 10.1016/j.jastp.2005.03.020.

Karpov I.V., Kshevetskii S.P. Formation of large-scale disturbances in the upper atmosphere caused by acoustic gravity wave sources on the Earth's surface. Geomagnetism and Aeronomy. 2014, vol. 54, no. 4, pp. 513-522. DOI: 10.1134/ S0016793214040173.

Karpov I.V., Kshevetskii S.P. Numerical study of heating the upper atmosphere by acoustic-gravity waves from a local source on the Earth's surface and influence of this heating on the wave propagation conditions. J. Atmos. Solar-Terr. Phys. 2017, vol. 164, pp. 89-96. DOI: 10.1016/ j.jastp.2017.07.019.
Karpov I.V., Borchevkina O.P., Dadashev R.Z., Ilminskaya A.V. Influence of meteorological storms on ionospheric parameters in the Baltic region in 2010. Solar-Terr. Phys. 2016, vol. 2, no. 2, pp. 77-81. DOI: 10.12737/21001.

Karpov I.V., Borchevkina O.P., Karpov M.I. Local and regional ionospheric disturbances during meteorological disturbances. Geomagnetism and Aeronomy. 2019, vol. 59, no. 4, pp. 458-466. DOI: 10.1134/S0016793219040108.

Kazimirovsky E., Herraiz M., Morena A.D.L.B. Effects on the ionosphere due to phenomena occurring below it. Surveys in Geophysics. 2003, vol. 24, iss. 2, pp. 139-184. DOI: 10.1023/ A:1023206426746.

Khromov S. P., Mamontova L. I. Meteorologicheskii slovar [Meteorological Dictionary]. Leningrad, Hydrometeo-izdat Publ., 1974, 568 p. (In Russian).

Koucká Knížová P., Mošna Z., Kouba D., Potužníková K., Boška J. Influence of meteorological systems on the ionosphere over Europe. J. Atmos. Solar-Terr. Phys. 2015, vol. 136, pp. 244-250. DOI: 10.1016/j.jastp.2015.07.017.

Kunitsyn V.E., Suraev S.N., Akhmedov, R.R. Modeling the propagation of acoustic gravity waves in the atmosphere for different surface sources. Vestnik Moskovskogo universiteta. Ser. Fizika. Asronomiya [Moscow University Physics Bulletin]. 2007, iss. 3, no. 2, pp. 59-63. (In Russian)

Laštovička $J$. Forcing of the ionosphere by waves from below. J. Atmos. Solar-Terr. Phys. 2006, vol. 68, no. 3, pp. 479497. DOI: 10.1016/j.jastp.2005.01.018.

Liperovsky V.A., Pokhotelov E.V., Liperovskaya E.V., Parrot M., Meister C.-V., Alimov O.A. Modification of sporadic E-layers caused by seismic activity. Surveys in Geophys. 2000, vol. 21, pp. 449-486. DOI: 10.1023/A:1006711603561.

Martinis C.R., Manzano. J.R. The influence of active meteorological systems on the ionosphere F region. Ann. Geophys. 1999, vol. 42, no. 1, pp. 1-7. DOI: 10.4401/ag-3708.

Mathews J.D., Sporadic E: current views and recent progress. J. Atmos. Solar-Terr. Phys. 1998, vol. 60, iss. 4, pp. 413435. DOI: 10.1016/S1364-6826(97)00043-6.

Parkinson M.L., Dyson P.L. Measurements of mid-latitude E-region, sporadic-E, and TID-related drifts using HF Dopplersorted interferometry. J. Atmos. Solar-Terr. Phys. 1998, vol. 60, iss. 5, pp. 509-522. DOI: 10.1016/S1364-6826(97)00058-8.

Pignalberi A., Pezzopane M., Zuccheretti E. Sporadic E layer at mid-latitudes: average properties and influence of atmospheric tides. Ann. Geophysic. 2014, vol. 32, iss. 11, pp. 14271440. DOI: 10.5194/angeo-32-1427-2014.

Pilipenko S. G., Kozak L. V. Wind shifts in the Earth's atmosphere over powerful hurricanes. Kosmicheskaya nauka $i$ tekhnologiya [Space Science and Technology]. 2012, vol. 18, no. 6, pp. 43-50. DOI: 10.15407/knit2012.06.043. (In Russian).

Polyakova A.S., Perevalova N.P. Comparative analysis of TEC disturbances over tropical cyclone zones in the North-West Pacific Ocean. Adv. Space Res. 2013, vol. 52, iss. 8, pp. 1416-1426. DOI: 10.1016/j.asr.2013.07.029.

Šauli P., Bourdillon A. Height and critical frequency variations of the sporadic-E layer at midlatitudes. J. Atmos. SolarTerr. Phys. 2008, vol. 70, iss. 15, pp. 1904-1910. DOI: 10.1016/ j.jastp.2008.03.016.

Schubert G., Hickey M.P., Walterscheid R.L., Physical processes in acoustic wave heating of the thermosphere. J. Geophys. Res. 2005, vol. 110, pp. D07106. DOI: 10.1029/2004 JD005488.

Scotto C., Sporadic-E layer and meteorological activity. Ann. Geophyse. 1995, vol. 38, no. 1, pp. 21-24. DOI: 10.4401/ag-4129.

Snively J.B., Pasko V.B. Breaking of thunderstormgenerated gravity waves as a source of short-period ducted waves at mesopause altitudes. Geophys. Res. Lett. 2003, vol. 30, iss. 24, pp. 2254. DOI: 10.1029/2003GL018436. 
Tupikin S.N. Structural analysis of storm winds in the South-Eastern Baltic and the Kaliningrad region. Kompleksnoe izuchenie basseina Atlanticheskogo okeana: Sb. nauchnykh trudov [Proc. "Comprehensive Study of the Atlantic Ocean Basin"]. Kaliningrad, 2003, pp. 59-63. (In Russian).

van Eyken A.P., Williams P.J.S., Maude A.D., Morgani G. Atmospheric gravity waves and sporadic-E. J. Atmos. SolarTerr. Phys. 1982, vol. 44, iss. 1, pp. 25-29. DOI: 10.1016/00219169(82)90089-7.

Zakharov V.I., Kunitsyn V.E. Regional features of atmospheric manifestations of tropical cyclones according to groundbased GPS network data. Geomagnetism and Aeronomy. 2012, vol. 52, no. 4, pp. 533-545. DOI: 10.1134/S0016793212040160.

URL: https://rp5.ru (accessed September 16, 2019).

How to cite this article

Borchevkina O.P., Karpov I.V., Karpov M.I., Korenkova N.A., Vlasov V.I., Leshchenko V.S. Impact of meteorological storms on the Eregion of the ionosphere in 2017-2018. Solar-Terrestrial Physics. 2020. Vol. 6. Iss. 4. P. 74-79. DOI: 10.12737/stp-64202011. 